\title{
Editorial
}

\section{New marketing - learning to lead, and leading to learn}

Real learning is and always will work best as an interactive one-to-one process. In contrast, we - author and readers - as products of the 20th century, have become accustomed to marketing communications models which are mass and dumb (non-interactive). The fact that technology is turning this century's marketing reality upside down suggests that an information revolution is an understatement of the times we are living through.

There is a sense in which we are all going back to childhood. Today, most consumers of the Internet have less than one year's experience of it. Take advantage of a child's curiosity in questioning its every meaning, and you have a window of opportunity to shape its future uses. You will also be in some surprisingly strong company. Bill Clinton made it one of his three final rallying calls for re-election: 'we're going to connect up the nation's schools to the Internet'. Today's most successful business man, Bill Gates, has only just recognised that the Internet is his company's core product. The reinvention of Microsoft in little more than a year sets a vital example of the drama of leadership and the extraordinary potential of the brand learning organisation.

I suggest a primary qualification for being a reader of this Journal is a passionate interest in exploring how companies organise growth of stakeholder value fairly for all involved. That is the Unique Organising Purpose of branding as envisioned by the new marketing concept. Interactive media will change everything - everything that marketing is, everything that learning organisation is, everything that leadership is. Robust theory is simply not a viable goal in attempt- ing to make an editorial grope towards marketing's future, so I may as well be provocatively self-indulgent.

Electronic learning - you have come of age. My first employment, 21 years ago, was with the computer assisted learning unit of the University of Leeds. We were experimenting with a new approach for acquiring statistical know-how with 10 computer terminals, one inexperienced tutor (me), 10 unwilling students (geographers for whom statistics examples practice was the least favourite part of their curriculum) wired across four replicate sites via telephone modems to one central computer.

This primitive interactive laboratory provided me with a glimpse of a different world from passively watching television screens. I observed some students engrossed in a good interactive experience with the computer, complimenting them repeatedly with rotated synonyms for 'good ... that's right'; others were going red in the face as their calculation of a statistical formula went wrong again and again, and I would try to intercept them with a bit of personal tuition. Others left looking exhausted - sometimes they had simply achieved an order of magnitude, namely more learning in an hour than ever before and in other cases my check of computerised traces of their sessions revealed one major learning block that I could put right by programming a tailored explanation to start up their next interactive session.

I knew then, that one day, electronic learning would change the world. In a generation's time, I vowed to experiment again - wherever my career took me.

Meanwhile ... fate took me on a journey 
through consumer research in 25 countries, to being a consultant on how company brand architectures need to be totally reorganised, if they are, to fairly involve all stakeholders, globally and locally. This is a banner branding process which is pivotal to the ways that the company of the future will consistently increase wealth or die and a process that works to accelerate learning connected to all of a company's core competences (the corporate roof according to Hamel and Prahalad's visioning of how companies will compete for the future). A network of co-workers and myself have amplified our action learning approach for implementing this elsewhere (see 'Brand Chartering Handbook - how brand organisations learn living scripts', 1996, Addison-Wesley \& EIU).

Fortunately, I remembered my vow to computerised learning just in time to ask another network of enthusiasts to set up a website for architects of marketing's future, MELNET (Marketing Expert Learning NETwork) www.brad.ac.uk/branding/.This encourages people to join in interactive learning experiences: ask authors questions, benchmark Brand Chartering experiences, exchange other frameworks for advancing marketing learning organisations. And wherever an urgent meeting of the minds occurs, we host E-mail summits. For example: our six favourite interactive book club summits of the moment are being built around:

- 'Brand Chartering', Macrae and WCBN co-workers (1996), Addison-Wesley \& EIU;

- 'Meeting of the Minds', Barabba (1995), Harvard Business School Press;

-- Marketing-Driven Management using the New Marketing Concept to create a Customer-Orientated Company', Webster (1994), Wiley;

- 'The Knowledge-Creating Company', Nonaka and Takeuhchi (1995), Oxford
University Press;

- 'The Witch Doctors', Micklethwait and Wooldridge (1996), Heinemann;

- 'Competing for the Future', Hamel and Prahalad (1994), Harvard Business School Press.

Before the beginning of 1996, I had never used E-mail. I struck a rich academic vein of learning with my third E-mail. It characterises how open an expert can be in this medium if you hit him or her with a question that is a passionate interest. It also served to confirm my hypothesis that the combination of globalisation and digitalisation of communications are changing how best to do most things I care most about professionally - branding, learning and organisations built for sustainable growth.

Chris Macrae: Today no university can organise a quality degree on its own. Networking partnerships are the name of the learning game now that computerisation means that the cost of learning is not primarily a function of the distance between participants.

University Vice Chancellor: I agree but this means that the nature of 'learning' is also changing - from an industrialised, conveyor belt, lecture-based model to a bespoke, individualised niche sensitive model.

CM: Even before the days of our blossoming informational era, some will observe an irony in the fact that entertainment programming already involves mature global networks whereas educational programming is only just learning the game. British academics who want to play a leading role in the future of higher education cannot afford to wait for another government sponsored report let alone one scheduled for publication in 1998. 
UVC: Agreed - but what are the majority of them going to do about it? The CVCP are as pleased as the government to be let off the hook and I doubt whether there will be much support for a unilateral attempt on the part of the universities to sort out their funding crisis this side of 1998. The British universities are quite capable of going the way of British Shipbuilding; Steel; Leyland - all of whom had ample warning of the consequences of impending structural change in their markets.

By Spring 1996, I was E-mailing America's best selling academic authors on branding to see who would like a complimentary copy of 'Brand Chartering Handbook'. Again good fortune struck as this E-mail testimonial a month later - from one of America's best-selling authors — records:

'I'm enjoying your new book. It's strange to see so many ideas I agree with and normally need to defend and explain. There is an exceptionally high density of ideas per page. It's like Tom Peters when it gets into a flow.'

These initial experiences - and a chance conversation with a Hong Kong client spurred me on to setting up a tripartite academic, practitioner, adviser - experiment: the world's first E-mail summit between forty new marketing/branding opinion leaders. We agreed this would be a slow-burn experiment with many participants too busy to look at any E-mails more than fortnightly. At time of writing, we are two months - eg four learning cycles old. And many more new marketing opinion leaders are joining us. The debate has exceeded my most optimistic expectations connecting branding up to the critical issues of leadership and learning. Perhaps, in 1994, Coopers \& Lybrand UK were misleading to point at marketers as being 'at the crossroads' without reflecting on problems higher up the organisation. Here is an extract of a dialogue, which began with what a former chairman of a leading UK FMCG company had to say.

Chairman: My conclusion is that on the whole it (a purposeful strategy for corporate brand leadership) is so major and so long term that it is outside the frame of reference of the average operating board to take it into account now in their planning. I think, sadly, they feel they'll be 'out of here' by the time it happens. 'Tis sad, 'tis pity and pity 'tis, 'tis true. Look at average tenure time on boards, however, and you get the context. I was interested in the New York Times' leaders all last week on CEOs who stay watertight (very heavily rewarded with deferred tax incentives) as their strategic plans for businesses crumble because they haven't read the key competitive signals, while of course the work force gets laid off, downsized etc. If the New York Times - hardly a radical bastion - says this, we have to believe it.

CM: My base scenario is that, by 2010 , Europe will be on irreversible slide towards being the third world continent (versus Asia and USA), and the UK will be the third world country within the third world continent, unless UK marketers (and all who seek to expand organisations) find a way to raise the leadership debate out of the vicious circle of short termism that today's boards of directors tend to foster. I would love to have the hope of being wrong - is there a UK optimist at the Summit?

Marketing VP: I also agree with the comments on the need to build more long termism in to the board level of major corporations which are being forced to deliver quarterly numbers. Our new Chairman has come up with some interesting perspectives. Get discussion around a 'market place' P\&L. The board will in 
future review tracking studies measuring Quality, Consumer Regard and Customer Regard as well as conventional financial measures. Suddenly continuity of management and indicators of sustainability are being taken more seriously.

Other urgent topics being debated at the Email summit include:

- a balanced scorecard of performance measurements;

- expert futures that question conventional marketing organisations;

- mass media made marketing too easy for the lazy?

- the future of brands in an on-line world;

- marketing's 'transferable truths';

- China's new marketing philosophy;

- efficient consumer response;

- marketing policy/strategy of nations;

- global brand and organisation - which drives which?

- mergers and acquisitions - with world class goals - why do so many fumble?

- integrating internal and external marketing;

- what are your models for value-adding origins of brands with a future?

I leave you with the script used to initiate a change debate on 'the end of television advertising' in a style that perhaps only E-mail assisted by my father Norman Macrae, futurist and ex-Deputy Editor of the Economist, could know how to pull off.

\section{How television advertising disappeared $^{1}$}

\section{Alias: A do-it-for-yourself tracking model - fact or fiction?}

A couple of preambles before I come to the beef on this one. You may wish to move straight to the beef, but be warned its aim is to knock you off the fence (on the power of television advertising) for ever.

\section{Preamble 1}

My father (who as it happened did predict the fall of the Berlin Wall and communism with 95 per cent accuracy - in two chapters of a 1984 book which also foresaw the Internet and a few other upcoming changes) taught me that there are three essential skills of forecasting:

- Be rude to conventional thinking. The good bits (and people) will stand up to your rudeness. The redundant bits blind people to unstoppable trends that are already happening. When blind people lead organisations, wealth production goes into reverse which I believe, historians have found to be the common 'critical failure factor' in the decline and fall of every great empire;

- Do not get buried in debate of numbers. You are searching for order of magnitude trends, so you need to know the numbers (and sometimes more importantly the counting conventions assumptions - that produce them) but those who insist that any argument must be documented in decimal points are probably not interested in leading the future anyway. Often, they are also the bureaucrats who are doing very nicely from the status quo.

- Stick to environments where big changes are really happening and where you understand the deep background. (Unless you do all three of these things, your forecasting will have somewhat less value than astrology.)

\section{Preamble 2}

Which of these three things is most important for leveraging excellent television advertising:
a) creativity;
b) targeting;
c) being endemic to an era of human ex- perience (social culture)? 
Of course, all three are important and should interact. But the simplest piece of my argument will be that mass media are only powerful while they are there (centre stage in the way that humans are). My vote in this multiple choice question is c) every time.

(Probably if I am still alive around 2005, I will arouse similar sound and fury in inferring the death of politicians/mass democracy, but let us return to new marketing which is where many modern wars start anyway.)

In spite of all the science of media targeting (advertising effectiveness et VALs) and all the art of creativity, James Webb Young said this in the simpler heyday of press advertising (second quarter of 20th century). But I think his point holds for all the old mass media which conventional organisations (with their internal political myopias) know too well to charter top of their minds.

'We can discover, I think, that there are five basic ways in which advertising works:

- By spreading news, not only news in the newspaper sense, but a special kind of news that only advertising, in the commercial way, can most widely deal with;

- by familiarising, that is, as the dictionary says by making "something well known; bringing into common use". We will see that this is the absolutely basic value created by advertising, the one underlying all others;

- by reminding - a function that may alone, in some cases, make advertising pay;

-- by adding a value not in the product the most challenging field for creativeness in advertising;

- by overcoming inertia - the great drag on all human progress, economic or non-economic, as represented in the sociological term "cultural lag".

This is probably the best 5-point set of transferable truths I have ever read. Maybe the UK Marketing Council (visit www.marketingcouncil.org) should adopt it as their vision statement.

\section{Before we get to the beef}

I do think Webb Young's five-point list is also spot on confirmation of my simpleminded answer c). If correct, the corollary is that while television media existed centre stage and were cheap, you all - not only you (the Economist's dead brand manager) nor just you (Cooper's downsizable marketing department) but you, all the way up the organisation (to short-termist company directors) could be lazy about your brand architecture. Your directors could sit back, blindfolded as to how marketing and strategy and organisational learning might work best if they were interconnected and let rip with a thousand different product brands fighting within your organisation - and all profitable! Furthermore, because of this, classical marketing models were taught in this way to MBAs and other functional experts and to the teachers themselves. Then, because of this, people started valuing brands by their apparent external signs of power rather than their integrated internal marketing consistency with the company's purpose, learning of vision/values, and unique competences. Then the blindest directors started criticising journalists who began asking whether brands were all image and no substance. So we of the simple-minded class of 1993/4 coined headlines to kill off brands, before branding's core as the Unique Organisational Process could be reborn.

\section{THE BEEF}

\section{Health warnings}

- Timelines vary: good branding communications in China today may resemble those in the UK of 1970. But even if 
this is true and if its people are who I think they are - their marketing-sophistication timeline may have overtaken the UK's by 2015. When my father made a similar prediction about the Japanese of 1960 versus Europe of 1980, he made one of his three most famously correct forecasts. Now I do not have my father's brain, but I revel in being rude to conventional thinking. I believe that up to 10 per cent of today's management consultants are worthwhile (their main value being in devil advocacy). Many of the rest deserve the epitaph of being as much value as 'The Witch Doctors', which is I understand the gist, as well as the title, of the book recently launched by the Economist journalists John Micklethwait and Adrian Wooldridge.

- I have pitched my anchor to the UK (because if I had to get the numbers out I probably could) but remember my level of debate is intentionally order of magnitude. Ask yourself is this fact of fiction? But don't worry about the precise scales for your next five minutes of thinking time...

\section{United Kingdom 1980-85}

Typically, adults spend most of their leisure time in front of the television. There are two main channels. There is no video channel and no PC. The typical adult watches over 15 hours of television a week. At least seven hours of programming exists which reaches (through its commercial spots) one third or more of the adult population. These advertisements become the most common reference point of social culture (they get replayed by jokes in newspaper and conversations during coffee breaks in offices and when people go out to drink and chat). Because of being 'central mass' and because of seven hours of space, it probably did not need more than passable advertising, and more than a product with $£ 10$ million revenue to sit back and advertise a very profitable brand.

\section{UK 1990-95}

Actually the picture has not changed so much that you would notice it as a revolutionary social paradigm, but the changes that are going on are irrevocable.

Most people have a video, but programmes taped-before-you-retrieve become cumbersome to store. It is probable that the video has only reduced live watching time by 10 per cent.

Some people have 20-channel cable television, and this is increasingly stealing the mass sports programming from the main old channels.

A few people surf (or in some other way have a PC-learning lifestyle as well as a television-watching one). While these people are few, they skew significantly to the young, high income, opinion leading section of the population. What has happened, therefore, is that there are now only 2-3 hours of mass space that has both big and sufficient opinion-leading audiences at the same time. The cost of using this has gone up by many orders of magnitude. If you are a famous brand (whose products need not change much and that can rely on an advertising history of 10 years ago), you can still blindly play the game very profitably if your sales revenues are in excess of 30 million. Otherwise you somehow have to structure around megabrands or corporate brands whose total revenues are over $£ 100$ million. (Or you have to be cleverly segmented around a mass of your own rather than the whole population; or very seasonal; or there are many other free media tricks - refer to Benetton, Häagen-Dazs or in the USA, a dinosaur called Barnie - which I might mail elsewhere.) But the big change is that you can no longer rely on average brand advertising to pay its way as you could 10 years ago. And thank goodness for that because it 
actually means that consumer goods now need to live up to their name in more than image.

\section{The year 2005}

The TC (combination of television, PC and telecommunications network) is here in total reality. My voice-activated controller allows me to access any of the following with equal ease:

- television (broadcast, cable or satellite);

- my own computerised favourite videos;

- the updating of 200 top new films of the year from a website open 24 hours a day;

- learning of any kind I choose (including the possibility to print out a book if I prefer it that way) or to interactively dialogue in a voice-activated E-mail summit with a world of people who share a passionate interest in the same subject matter;

- other essentials of life, like shopping information;

- a lot of other things beyond my limited 1996 imagination.

The truth is the technology of the TC will be there by 2005. (Or Bill Gates' Microsoft will have gone bust as will America Inc. whose masterplan for the third millennium is to dominate the value added of this industry in the way that Hollywood did the mass marketing era.)

But there will not be quality/value of the product range quite up to the vision just expressed for a few years longer. But is the television advertising spot still centre-stage to the economics of new marketing? Yes: in one respect, there will be a few great programmes with contents that people will still want to watch universally live. No doubt of that. But the commercial breaks closest to those will only be affordable by the CocaCola's of this world. However, Coca-Cola will not be the brand I think it is if it believes that the live television advertisement spot of 2005 is the indispensable essence of its marketing. Now go back to James Webb Young's list. Which of them can be made even more meaningful if marketers - communications architects - lead interactive media (Webbsites included) properly now?

\section{Chris Macrae Editorial Board}

\section{Reference}

(1) Copyright 1996 MELNET coworkers.

\section{ESSENTIAL FURTHER READING IN THE JOURNAL OF BRAND MANAGEMENT}

This issue: Whither branding, William Ramsay;

This issue: The employer brand, Tim Ambler and Simon Barrow;

February 96: An invitation to join MELNET, Chris Macrae;

February 96: Misconceptions about brands, David Aaker;

December 95: Brand Chartering, Helena Rubinstein;

December 95: Brand Strategy Concepts that drive the business, Andy Mosmans;

October 95: Brand Architecture reconfiguring organisations, Mark Uncles et al.;

August 94 to March 95: Branding a core business process (JBM Series), Chris Macrae;

October 94: Whither Brand Management?, Michael Thomas;

October 93: Brand reengineering - why and how, Chris Macrae, Jeff Devlin et al. 